\title{
ALLOZYME BASED GENETIC VARIATION BETWEEN HATCHERY AND NATURAL POPULATIONS OF SAHAR (TOR PUTITORA)
}

\author{
S.K. Wagle ${ }^{1}$, N. Pradhan ${ }^{1}$, T.B. Gurung ${ }^{1}$ and J.D. Bista ${ }^{2}$
}

\section{ABSTRACT}

Sahar (Tor putitora) formed a substantial natural fishery in the major riverine and lacustrine ecosystem of Nepal. Biological diversity of this species is being threatened by various anthropogenic activities. In view of the conservational value and the aquaculture potential of $T$. putitora, significant development in artificial propagation of this species has been achieved. The successful hatchery production of $T$. putitora brought to the forefront problematic questions regarding genetic variation of the hatchery stocks. A study was, therefore, conducted to determine the genetic variability within and between hatchery stocks and their wild counterparts of $T$. putitora using allozyme markers.

Analyses of seven enzyme systems resuled in 11 loci being resolved from lake population and two consecutive generations of hatchery populations of $T$. putitora. Based on five polymorphic loci, all populations had percentage polymorphic loci 45.45 . Significant reduction $(P<0.01)$ in number of alleles per locus was evident in hatchery populations $(1.45 \pm 0.181)$ compared to lake population $(1.72 \pm 0.90)$. Loss of rear alleles, $E S T-2 * 74, I D H^{*} 70$ and $G D H^{\star} 33$ occurred in both of the hatchery populations which were present in wild counterparts- the lake population. All populations under study conform to the Hardy-Weinberg equilibrium at the $1 \%$ level. Although not significant $(P>0.05)$, observed heterozygosity increased in first generation of hatchery population $\left(H_{0}=0.181 \pm 0.233\right)$ compared to natural population $\left(H_{0}=0.179 \pm 0.221\right)$. The $H_{\circ}$ of second generation of hatchery population was lowest $(0.119 \pm 0.143)$ among the populations studied. Loss of rare alleles from the two generations of hatchery population, while these alleles were present in corresponding natural populations suggested the founders (20-30 individuals) of the hatchery populations probably represented bottlenecks to very small effective population size $\left(N_{e}\right)$.

Keywords: alleles, allozyme marker, heterozygosity, natural fisheries, variability

\section{INTRODUCTION}

Fish of genus Tor, commonly referred to as the sahar or mahseers, are important to transhimalayan mid hill regions for biodiversity reasons, and are also sought after as high-valued

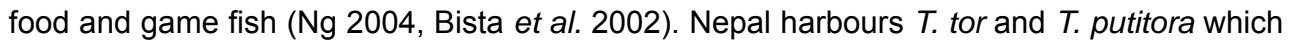
are commonly known as golden mahseer. T. putitora is most prevalent and live in headwaters of major river systems of Nepal. This species of mahseer formed a substantial natural fishery in the major riverine and lacustrine ecosystem of the country (Gurung et al. 2003). Despite their importance, their biological diversity is being threatened by various anthropogenic such as urbanization, habitat fragmentation, over-exploitation and ecological alterations and physical changes in natural environment (Swar 2002, Gurung et al. 2003). These has resulted in depletion of natural stocks of $T$. putitora to such an extent that they have been identified as critically endangered species (Islam 2002). 
In view of the conservational value and the aquaculture potential of T. putitora, there has been a concerted effort to artificially propagate this species. Since the T. putitora fetch a very high market price and is of high cultural value. Recognizing the importance of T. putitora, Nepal Agricultural Research Council (NARC), made a concerted attempts to evaluate its aquaculture potential, including captive breeding using long term pond reared broodstocks commencing in the period late 1980s. In early days of $T$. putitora domestication process, captive breeding of this species was based on wild caught, mature fish from lake and rivers (Gurung et al. 2002). Later in 1995, Fisheries Research Stations, Pokhara and Trishuli were able to captive breed T. putitora derived directly from progeny of the wild stocks. Recent hatchery productions of T. putitora are coming from the second generation of hatchery bred broodstocks. Hatchery produced offspring of this species are being used to stock enhancement in several natural water and to evaluate aquaculture potential in ponds.

The successful hatchery production of $T$. putitora brought to the forefront problematic questions regarding genetic variation of the hatchery stocks (broodstock). Long-term management of aquaculture production and conservation of this species would require information on levels of genetic variability within and among stocks which permits fish breeders to avoid potential detrimental effects of inbreeding and other genetic changes from one generation to another (Gjedrem 1992, Nguyen et al. 2005).

There have been documented cases in many fish species of genetic changes and loss of genetic variability in hatchery-reared stocks, such as in rainbow trout, Oncorhynchus mykiss (Koljonen 1986), guppy, Siamese fighting fish, Betta splendens (Meejui et al. 2005), Atlantic salmon, Salmo salar (Koljenon et al. 2002). Alteration of genetic diversity of wild counterparts would result due to interbreeding with escapees of hatchery-reared stocks (Cliford et al. 1998) or those used for restocking (Hinder et al. 1991). Genetic variation of hatchery populations of these species decreased due to small effective numbers of founders and/or genetic drift that occurred during the maintenance of the broodstock (Allendorf and Phelps 1980). Direct genetic interactions between wild and hatchery fish have been demonstrated in many studies (Simons et al. 2006). Hatchery-propagated Atlantic salmon were found to compete directly with native salmon for resources such as space, food or mates, alter predation regimes and transfer disease and parasites (Fleming et al. 2000). Such cases demonstrated problems that may rise in other species as well (Utter 2003).

Genetic variability is pivotal to maintaining the capability of restocked fish to adapt to a new or changing environment (Avise 1994). For conservation purpose, a successful restocking program depends largely on a broodstock management strategy that ensures maintenance of a wide gene pool (Nguyen et al. 2006). This minimize adverse effects on the genetic diversity of wild populations once stock enhancement commences, thereby helping to maintain the genetic integrity of the species under consideration (Vrijenhoek et al. 1985). The lack of genetic study to determine the genetic variability within and between hatchery stocks and their wild counterparts of $T$. putitora promoted the present study, the results of which may help in design of hatchery stock management strategy and subsequent application to future aquaculture production and genetic conservation strategies (Laikre et al. 1999). The objective of this study was to quantify genetic variation of lacustrine population and hatchery stocks of $T$. putitora 
maintained at Fisheries Research Centre, Pokhara, Nepal, using allozymes. The data have been used to discuss the implication for management of this species including aquaculture and conservation developments.

\section{MATERIALS AND METHODS}

\section{Collection of Fish Samples}

Forty wild-fish specimens of $T$. putitora were collected using gill net from lake Phewa (423 ha, $28^{\circ} 13^{\prime} \mathrm{N}, 84^{\circ} 00^{\prime} \mathrm{E}$ ). Live fish (40 individual/population) from the hatchery-reared two subsequent generations were taken from Fisheries Research Centre, Pokhara, where hatchery propagation of this species is being undertaken since 1995. Foundation stock of T. putitora directly served as parents for hatchery population I. Hatchery population II was consecutive generation of hatchery population I.

The live and gill net caught fish were subsequently sacrificed for muscle and liver tissues. The tissue samples were immediately frozen and transported to Biotechnology laboratory at Kathmandu. Frozen tissues were stored at $-40{ }^{\circ} \mathrm{C}$ in the laboratory until electrophoresis.

\section{Isozyme Analyses}

Seven enzyme systems were analyzed following methods described by Morizot and Schmidt (1990) and Hara and Na-Nakorn (1996). Horizontal starch gel (11\% w/v hydrolyzed potato starch) electrophoresis was operated in appropriate buffer systems. All electrophoresis runs were performed at $100 \mathrm{~V}$ and $40 \mathrm{~mA}$ for 16 hours. Tissue, enzyme systems, E.C. numbers, buffer system and the resolved loci are shown in Table 1. Chemical visualization followed Morizot and Schmidt (1990). Gene nomenclature suggested by Shaklee et al. (1990) was used.

Table 1. Names of enzyme systems, their E.C. number, tissue and buffer used, and the resolved loci.

\begin{tabular}{|c|c|c|c|}
\hline Names of enzyme & E.C. number & Tissue & Loci \\
\hline Isocitrate dehydrogenase (IDH) & E.C.1.1.1.42 & $\mathrm{L}$ & $I D H^{*}$ \\
\hline \multirow[t]{2}{*}{ Esterase (EST) } & E.C.3.1.1.1 & $\mathrm{L}$ & $E S T-1^{*}$ \\
\hline & & & EST-2* \\
\hline \multirow[t]{2}{*}{ Malate dehydrogenase (MDH) } & E.C.1.1.1.37 & $\mathrm{M}$ & sMDH-1* \\
\hline & & & sMDH-2* \\
\hline \multirow[t]{2}{*}{ Malic enzyme (ME) } & E.C.1.1.1.40 & $M$ & $M E-1^{*}$ \\
\hline & & & $M E-2^{*}$ \\
\hline \multirow[t]{2}{*}{ Sorbitol dehydrogenase (SDH) } & E.C.1.1.1.14 & $\mathrm{M}$ & $S D H-1^{*}$ \\
\hline & & & $\mathrm{SDH}-2^{*}$ \\
\hline $\begin{array}{l}\text { Glucose-6-phosphate dehydroge- } \\
\text { nase (G6PD) }\end{array}$ & E.C.1.1.1.49 & M & G6PD* \\
\hline Glucose dehydrogenase (GDH) & E.C.1.1.1.47 & L & $G D H^{*}$ \\
\hline
\end{tabular}

$\mathrm{L}=$ liver, $\mathrm{M}=$ muscle

Buffer: Tris-citrate $\mathrm{pH} 8.0$ 


\section{Data Analyses}

Individual genotypes were used for the calculation of allele frequencies, percentage of polymorphic loci (a locus was considered polymorphic if the frequency of the most common allele was 0.95 or less), average and effective number allele per locus, observed and expected heterozygosity (Nei 1978). The calculations were performed by the POPGENE version 1.32 (Yeh and Boyle 1997). Differences in heterozygosity between populations were tested using independent sample comparisons (Archie 1985).

Populations were tested for Hardy-Weinberg equilibrium using Markov chain method (demorization $=1000$, batches $=20$, iteration per batch $=1000$ ). Locus-wise $F_{\text {is }}$ (Weir and Cockerham 1984) were calculated within each of the populations and significance level were Bonferoni corrected (Rice 1989). Wright's F-statistic approach (Wright 1951, 1978) and its exact test were calculated to test for genetic population structure. Population differentiation was tested using the Markov chain method. All these calculations were preformed by the GENEPOP version 3.3 (Raymond and Rousset 1995). The software TFPGA (Miller 1997) was used to calculate genetic distances (Nei 1972, 1978).

\section{RESULTS AND DISCUSSION}

Based on 5 polymorphic loci, the natural population had mean number of alleles per locus of $1.72( \pm 0.90)$, percentage polymorphic loci $=45.45$, mean observed and expected heterozygosity $\left(\mathrm{H}_{\mathrm{o}}, \mathrm{H}_{\mathrm{e}}\right)=0.179( \pm 0.221)$ and $0.184( \pm 0.196)$, respectively (Table 3 and 4$)$.

Analyses of seven enzyme systems resuled in 11 loci being resolved from the two consecutive generations of hatchery populations of $T$. putitora. Five loci were polymorphic (a locus was considered polymorphic if a frequency of most common allele did not exceed $0.95-\mathrm{P}_{.95}$, EST-2*, SMDH-1*, IDH*, GDH* and MEP-1*. Allele frequencies of the polymorphic loci are shown in Table 2.

Table 2. Allele frequencies of eleven polymorphic allozyme loci in three populations of Tor putitora from lake and hatchery of Pokhara Valley, Nepal.

\begin{tabular}{|l|l|l|l|l|}
\hline Loci & \multicolumn{4}{|l|}{ Allele frequencies } \\
\hline & Allele & Phewa Lake & Hatchery pop. I & Hatchery pop. II \\
\hline EST-2* & 116 & 0.371 & 0.325 & 0.150 \\
\hline & 100 & 0.611 & 0.675 & 0.850 \\
\hline & 74 & 0.018 & 0 & 0 \\
\hline & & & & \\
\hline$I D H^{\star}$ & 100 & 0.656 & 0.875 & 0.900 \\
\hline & 83 & 0.281 & 0.125 & 0.100 \\
\hline & 70 & 0.063 & 0 & 0 \\
\hline & & & & \\
\hline$G D H^{\star}$ & 174 & 0.250 & 0.525 & 0.235 \\
\hline & 100 & 0.694 & 0.475 & 0.765 \\
\hline & 33 & 0.056 & 0 & 0 \\
\hline & & & & \\
\hline
\end{tabular}




\begin{tabular}{|l|l|l|l|l|}
\hline SMDH-1* & 100 & 0.333 & 0.625 & 0.792 \\
\hline & 51 & 0.667 & 0.375 & 0.208 \\
\hline & & & & \\
\hline MEP-1* & 100 & 0.750 & 0.800 & 0.607 \\
\hline & 39 & 0.250 & 0.200 & 0.393 \\
\hline
\end{tabular}

The number of alleles per locus within hatchery populations was $1.45( \pm 0.52)$, percentage polymorphic loci was $45.45 \%$ (Table 3 ). Paired sample T-test revealed that both hatchery populations exhibit significantly lower $(P<0.05)$ number of alleles per locus compared to that of natural population.

Loss of rear alleles, EST-2*74,IDH*70 and $G D H^{\star} 33$ occurred in both of the hatchery populations compared to their wild counterparts - the lake population, although they were present at frequencies $\leq 0.05$ in natural population with exception those at $I D H^{*} 70$. Given a frequency of lost alleles, the chance of drawing no individuals showing the rare alleles in a sample can be calculated as: frequency of alternate alleles $(2 \times$ number of individual) (Dillon and Manzi 1987). The chance of completely missing allele EST-2*74 in the sample of 31 for both of the hatchery populations was 0.30 . There is fair chance that this allele is present in hatchery populations, but was missed in the sample. However, the chance of completely missing allele $I D H^{\star} 70$ and $G D H^{\star} 33$ in the sample of hatchery populations was just 0.017 and 0.035 , respectively. Thus it seems likely that the hatchery populations have indeed lost these alleles.

Effective number of alleles per locus $\left(\mathrm{N}_{\mathrm{e}}\right)$ was calculated for each population thus diminishing the contribution of rare alleles. $N_{e}$ decreased significantly $(P<0.05)$ in subsequent generation of hatchery populations. Significant differences $(P<0.05)$ were also observed in between $N_{e}$ of natural population $(1.37 \pm 0.44)$ and hatchery population I $(1.31 \pm 0.4)$ and hatchery population II (1.23 \pm 0.31$)$.

Table 3. Measures of genetic variability (number of alleles per locus $\pm S D$ in parentheses, effective number of alleles per locus $\pm S D$ in parentheses, percentage of polymorphic loci and mean sample size per locus at eleven loci) within hatchery and lake populations of Tor putitora in Pokhara Valley, Nepal.

\begin{tabular}{|c|c|c|c|c|}
\hline $\begin{array}{l}\text { Popula- } \\
\text { tion }\end{array}$ & $\begin{array}{l}\text { No. sam- } \\
\text { ples per lo- } \\
\text { cus }\end{array}$ & $\begin{array}{l}\text { No. alleles } \\
\text { per locus } \\
\text { ( } \pm \text { SD) }\end{array}$ & $\begin{array}{l}\text { Effective number } \\
\text { of alleles per locus } \\
( \pm S D)\end{array}$ & Polymorphic loci (\%) \\
\hline Lake & 25.5 & $1.72(0.90)^{\mathrm{a}}$ & $1.37(0.44)^{a}$ & 45.45 \\
\hline Hatchery I & 16.5 & $1.45(0.52)^{b}$ & $1.31(0.40)^{\mathrm{b}}$ & 45.45 \\
\hline Hatchery II & 14.5 & $1.45(0.52)^{\mathrm{b}}$ & $1.23(0.31)^{\mathrm{c}}$ & 45.45 \\
\hline
\end{tabular}

Superscripted with the same letter in a column are not statistically different $(P>0.05)$ between 
populations (Archie 1985)

\# 95\% criterion

$H_{o}$ was between $0.181( \pm 0.233)$ to $0.119( \pm 0.143)$ and $H_{e}$ was between $0.176( \pm 0.216)$ to 0.145 $( \pm 0.181)$ for hatchery populations I and II, respectively (Table 4). There were no differences $(\mathrm{P}<0.05)$ in $\mathrm{H}_{\mathrm{o}}$ between hatchery populations. However, lower $\mathrm{H}_{\mathrm{o}}(\mathrm{P}<0.01)$ was evident in hatchery population II when compared with the natural population. Independent sample comparison (Archie 1985) revealed that there is no significant different in observed and expected heterozygosity after bonferroni correction $(P>0.003)$ within populations. All populations under study conform to the Hardy-Weinberg equilibrium at the $1 \%$ level after Bonferroni correction (Rice 1989).

Table 4. Measures of genetic variability (mean heterozygosity: observed and expected, fixation index $\left(F_{i s}\right)$, Hardy-Weinberg exact test value* (Bonferroni corrected; $P=0.003$ ) within hatchery and lake populations of Tor putitora in Pokhara Valley, Nepal.

\begin{tabular}{|l|l|l|l|l|l|}
\hline Population & \multirow{2}{*}{$\begin{array}{l}\text { No. samples } \\
\text { per locus }\end{array}$} & \multicolumn{2}{|l|}{ Average heterozygosity } & \multirow{2}{*}{$\mathbf{F}_{\text {is }}{ }^{\text {}}$} & P \\
\cline { 3 - 4 } & & $\mathrm{H}_{\mathrm{o}}( \pm \mathrm{SD})$ & $\mathrm{H}_{\mathrm{e}}( \pm \mathrm{SD})^{+}$ & & \\
\hline Lake & 25.5 & $0.179(0.221)^{\mathrm{a}}$ & $0.184(0.196)$ & 0.02 & 0.4316 \\
\hline Hatchery I & 16.5 & $0.181(0.233)^{\mathrm{ab}}$ & $0.176(0.216)$ & 0.02 & 0.6414 \\
\hline Hatchery II & 14.5 & $0.119(0.143)^{\mathrm{b}}$ & $0.145(0.181)$ & 0.17 & 0.0111 \\
\hline
\end{tabular}

" Markov chain method

+ Nei's expected heterozygosity

$æ \mathrm{~F}_{\text {is }}=\left(\mathrm{H}_{\mathrm{e}}-\mathrm{H}_{\mathrm{o}}\right) / \mathrm{H}_{\mathrm{e}}$.

Superscripted with the same letter in a column are not statistically different $(P>0.05)$ between populations (Archie 1985).

Most of the locus wise $F_{\text {is }}$ values within each population (Table 5) were not different from 0 $(P>0.01)$ after Bonferroni correction. Among the significant test lake population was at $G D H^{*}$, hatchery population I at $S M D H-1^{*}$ and hatchery population II was at MEP-1*. The $\mathrm{F}_{\text {is }}$ values for $S M D H-1^{*}$ was relatively high in both wild and hatchery populations.

Table 5. Locus-wise $F_{\text {is }}$ (Weir and Cockerham 1984) within each of 3 populations of $T$. putitora in Pokhara Valley, Nepal.

\begin{tabular}{|l|l|l|l|}
\hline Locus & Phewa Lake & Hatchery Pop. I & Hatchery Pop. II \\
\hline$E S T-2^{*}$ & -0.117 & -0.000 & -0.152 \\
\hline$I D H^{*}$ & 0.385 & -0.077 & -0.059 \\
\hline$G D H^{\star}$ & $0.410^{* *}$ & -0.280 & 0.050 \\
\hline
\end{tabular}




\begin{tabular}{|l|l|l|l|}
\hline$S M D H-1^{*}$ & 0.270 & $0.486^{* *}$ & 0.283 \\
\hline$M E P-1^{*}$ & -0.318 & -0.200 & $0.576^{* *}$ \\
\hline
\end{tabular}

"Statistically significant $(P<0.002-B o n f e r r o n i$ correction $)$

$\mathrm{F}_{\mathrm{st}}(0.0529)$ did not show significantly population differentiation among the hatchery populations (Table 6). Pair-wise genetic differentiation was also not significant in all loci of the two hatchery populations. The genetic distance $(\mathrm{Nei} 1972,1978)$ between the T. putitora populations are presented in Table 7. Genetic distance between the two hatchery populations was 0.0195 (Nei, 1972) and 0.0127 (Nei 1978), with greater distance of 0.0371 (Nei 1972) and 0.0308 (Nei 1978) between the wild population and hatchery population II, descendent of hatchery population I. However, the Nei's genetic distance ranged from 0.0127 to 0.0371 falls within the range of conspecific.

Table 6. Values for F-statistics of hatchery populations of Tor putitora in Pokhara valley, Nepal.

\begin{tabular}{|l|l|l|}
\hline Locus & $\mathbf{F}_{\text {is }}$ & $\mathbf{F}_{\text {st }}$ \\
\hline$E S T-2^{*}$ & -0.0556 & $0.0589^{*}$ \\
\hline$I D H^{*}$ & -0.0684 & -0.0520 \\
\hline$G D H^{*}$ & -0.1537 & 0.1420 \\
\hline$S M D H-1^{*}$ & 0.4268 & $0.0159^{*}$ \\
\hline$M E P-1^{*}$ & 0.3307 & $0.0275^{*}$ \\
\hline
\end{tabular}

\begin{tabular}{|l|l|l|}
\hline Average & 0.1212 & 0.0529 \\
\hline Jacknifing over loci $( \pm S D)$ & $0.1262(0.1415)$ & $0.0559(0.0344)$ \\
\hline
\end{tabular}

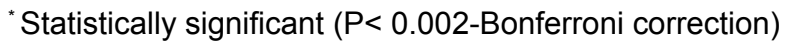

Table 7. Genetic distance for the three Tor putitora populations according to the methods of Nei (1972) below the diagonal and Nei (1978) above the diagonal.

\begin{tabular}{|l|l|l|l|}
\hline Population & Lake pop. & Hatchery pop. I & Hatchery pop II \\
\hline Phewa Lake & $* * * *$ & 0.0149 & 0.0308 \\
\hline Hatchery pop. I & 0.0217 & $* * * *$ & 0.0127 \\
\hline Hatchery pop II & 0.0371 & 0.0195 & $* * * *$ \\
\hline
\end{tabular}

In order to interpret the level of the genetic variation of the hatchery stocks, the data of their wild counterpart-the lake population was used as a baseline. Lake population has served the founding stock of the hatchery populations. However, the interpretation presented here should be taken with caution because of the small number of allozyme loci were used to describe 
genetic variation of natural and hatchery populations of $T$. putitora.

Considerable reduction of genic variability was found in the hatchery populations, as summarized in Table 3 and 4 . The magnitude of reduction was $18.6 \%$ in the average number of alleles per locus, $7.8 \%$ in the average number of effective alleles $\left(\mathrm{N}_{\mathrm{e}}\right)$ per locus in both of the hatchery populations, and $33.3 \%$ in the observed heterozygosity in hatchery population II relative to data from the natural population.

The loss of rare alleles is quite common in hatchery populations. It would occur initially because of a founder effect, the situation in which small numbers of brooders were taken from the natural population for domestication (Allendorf and Phelps 1980, Norris et al. 1999). The populations keep facing allele loss during domestication process due to inbreeding and or genetic drift (Fujio et al. 1999). The effect of allele loss have been clearly demonstrated in hatchery populations of fish and shellfish; for example, Atlantic salmon, Salmo salar (Koljenon et al. 2002);

Abalone, $H$. rubra (Evans et al. 2004) and hard calm, Mercenaria marcenaria (Dillon and Manzi 1987).

Observed heterozygosities $\left(H_{0}\right.$ mean $=0.150$; ranged between 0.181 and 0.119$)$ observed in this study were quite high compared to $\mathrm{H}_{\mathrm{o}}$ of hatchery populations of other species, based on same marker types (with large numbers), such as Beta splendens $\left(\mathrm{H}_{\mathrm{o}}=0.099\right)$ (Meejui et al. 2005); black sea bream, Acanthopagrus schlegeli $\left(\mathrm{H}_{\mathrm{o}}=0.048-0.052\right)$; Oreochromis mossambicus $\left(H_{0}=0.073\right)$; common carp $\left(H_{0}=0.074\right)$; guppy $\left(H_{0}=0.054\right)$ (Macaranas and Fujio 1990). However, a drastic reduction in heterozygosity $(33.3 \%)$ of hatchery population II relative to natural population was the evidence in the present study. Generally heterozygosity of hatchery populations tend to decline due to increased inbreeding rate which was the result of small effective population size (Falconer 1983).

With respect to low allelic diversity, founder effect could explain such a genetic change in hatchery populations and may result from the sampling variation when founders were taken from natural population, i.e., random genetic drift- the smaller founding population. Random genetic drift associated with selection and inbreeding has also been suggested as possible causes of genetic variability in hatchery populations (Allendorf and Phelps 1980). In the hatchery population I examined here, the effect of selection and inbreeding may be disregarded, since no intentional selection was applied to the stock and no evidence of inbreeding was observed as revealed by high heterozygosity, lack of population specific nature of locus-wise $F_{\text {is }}$ and $\left(\mathrm{H}_{\mathrm{e}}-\mathrm{H}_{\mathrm{o}}\right) / \mathrm{H}_{\mathrm{e}}$ near equity. Thus the founder effect, i.e., the small number of parents having actually contributed to the reproduction of hatchery population I.

Low heterozygosity accompanying with low allelic diversity in hatchery population II might have been resulted from inbreeding. Evidence of inbreeding was observed in this population as revealed by an increase in homozygosity and the indicator of inbreeding $\left(\left(\mathrm{H}_{\mathrm{e}}-\mathrm{H}_{\mathrm{o}}\right) / \mathrm{H}_{\mathrm{e}}\right)$ value. It is likely that number of effective parents (effective population size) were much smaller than the numbers of fish used to produce hatchery population II. It seems essential to make efforts to increase the number of fish which contribute to reproduction of subsequent generation. Kapuscinski and Jacobson (1979) recommended that inbreeding could be minimized if effective population size $\left(N_{e}\right)$ exceeded 50 or by using a number of brooders at between 263 and 344 
fish per generation (Tave 1986).

Loss of alleles is a major concern for sustainability of the stocks in the long term because rare alleles are frequently associated with fitness traits (Allendorf and Phelps 1980). Population bottlenecks (founding of a stock) often have a greater effect on allelic diversity than on heterozygosity. To help reduce the founder effect, including losses of rare alleles, Allendorf and Ryman (1987) suggested that a founding population of at least 25 females and 25 males is a reasonable absolute minimum and they urged that efforts be taken to equalize the contribution of all founders. However, the present captive stocks of $T$. putitora should be supplemented periodically with wild genetic material, provided appropriate wild stocks are available. Despite there is no ideal frequency and proportion of such infusions from the wild (Edds and Echelle 1989), Allendorf and Ryman (1987) conservatively stated that a $10 \%$ contribution of wild fish every second or third generation would be sufficient under most circumstances. In this connection, much smaller infusions on the order of one effectively breeding individual of $T$. putitora per generation can considerably reduce effects such as loss of alleles in founding populations and subsequent selection and genetic drift in captivity.

\section{ACKNOWLEDGEMENT}

This study was supported by the funding obtained by Nepal Agricultural Research Council (NARC) under Project No.: 32061002. We thank the individuals who collected specimen for protein electrophoresis analysis: Mr. Ram Kumar Shrestha and Dev Prasad Sharma, Fisheries Research Centre, Pokhara. Thanks are also due to Dr. Hari Prasad Bimb for permitting the use of the facilities of the Biotechnology Laboratory of Agriculture Botany Division of NARC, Khumaltar, and laboratory staffs for technical assistance.

\section{REFERENCES}

Allendrof, F.W. and S.R. Phelps,1980. Loss of genetic variation in hatchery stock of cutthroat trout. Trans. of the Ame. Fish. Soc., 109:537-543.

Allendorf, F.W. and N. Ryman,1987. Genetic management of hatchery stocks. In Rayman, N. and F. Utter (eds) Population genetics and fisheries management. University of Washington press, Seattle, WA, pp 141-159.

Archie, J.W.,1985. Statistical analysis of heterozygosity data: independent sample comparisons. Evolution, 39(3):623-637.

Avise, J.C.,1994. Molecular markers, natural history, and evolution. Chapman and Hall, New York.

Bista, J.D., B.R. Pradhan, A.K. Rai, R.K. Shrestha and T.B. Gurung, 2002. Nutrition, feed and feeding of golden mahaseer (T. putitora) for domestication and production in Nepal. In Petr, T. and S.B. Swar (eds) Cold water fisheries in the Trans-Himalayan region. FAO Fisheries Technical Paper No. 431:376 p.

Cliford, S.L., P. McGinnity and A. Ferguson,1998. Genetic changes in Atlantic salmon (Salmo salar) populations of northwest Irish rivers resulting from escapes of adult farmed salmon. Can. J. Fish. Aquat. Sci., 55:358-363. 
Dillon, R.T. and J.J. Manzi,1987. Hard clam, Mercenaria mercenaria, broodstocks: Genetic drift and loss of rare alleles without reduction in heterozygosity. Aquaculture, 60:99-105.

Edds, D.R. and A.A. Echelle,1989. Genetic comparisions of hatchery and natural stocks of small endangered fishes: leon spring pupfish, comanche springs pupfish, and pecos gambusia, Trans. of the Ame. Fish. Soc., 118:441-446.

Evans, B., J. Bartlett, N. Sweijd, P. Cook and N.G. Elliott, 2004. Loss of genetic variation at microsatellite loci in hatchery produced abalone in Australia (Haliotis rubra) and South Africa (Haliotis midae). Aquaculture, 233:109-127.

Falconer, D.S.,1983. Introduction to quantative genetics, Longman Group Limited, New York (2nd edition).

Fleming, I.A., K. Hindar and I.B. Mjolnerod, 2000. Lifetime success and interactions of farm salmon invading a native population. Proc. R. Soc. Lond., B Biol. Sci., 267:1517-1523.

Fujio, Y., M. Nakajima and A.A. Barinova,1999. Decrease of effective population size during maintenance of guppy strain. Fish. Sci., 65:362-366.

Gjedrem, T.,1992. Breeding plans for rainbow trout. Aquaculture, 100:1-10.

Gurung, T.B., A.K. Rai, P.L. Joshi, A.P. Nepal, A.K. Baidya and J.D. Bista, 2002. Breeding of pond reared golden mahaseer (T. putitore) in Pokhara, Nepal. In Petr, T. and S.B. Swar (eds) Cold water fisheries in the Trans-Himalayan region. FAO Fisheries Technical Paper No. 431. 376 p.

Gurung, T.B., J.D. Bista, S.K. Wagle, A.K. Rai and S. Kumar, 2003. Fishery resources of Himalayan Golden Sahar (Tor putitora, Hamilton) in Nepal, Paper presented in International Conference on Himalayan Biodiversity Conservation. 22-25 Feb. 2003, Kathmandu, Nepal.

Hara, M. and U. Na-Nakorn,1996. Development of sustainable aquaculture technology in Southeast Asia. Final Report Submitted to NRCT, Thailand.

Islam, M.S., 2002. Evaluation of supplementary feeds for semi-intensive pond culture of mahaseer, Tor putitora (Hamilton). Aquaculture, 212:263-276.

Kapuscinski, A.R. and L.D. Jacobson,1979. Genetic guidelines for fisheries management. cited after FAO, 1988. Report of the EIFAC Technical Consultation on Genetic Broodstock Management and Breeding Practices of Finfish. EIFAC Occasional Paper No. 22: 15 p.

Koljonen, M.L.,1986. The enzyme gene variation of ten finfish rainbow trout strain and the relation between growth rate and mean heterozygosity. Aquaculture, 57:253-260.

Koljenon, M.L., J. Tähtinen, M. Säisä and J. Koshiniemi, 2002. Maintenance of genetic diversity of Atlantic Salmon (Salmo salar) by captive breeding programme and the geographic distribution of microsatellite variation. Aquaculture, 212:69-92.

Laikre, L., A. Antunes, A. Apostilidis, P. Berrebi, N. Ryman and C. Triantaphyllidis,1999. Conservation genetic management of brown trout (Salmo trutta) in Europe: Report by the concerted action on identification, management and exploitation of genetic resources in the brown trout (Salmo trutta). Trout Concert, EU Fair CT 97-3882. 
Macaranas, J. and Y. Fujio,1990. Strain differences in cultured fish-isozymes and performance traits as indicators, Aquaculture, 85:69-82.

Miller, M.P.,1997. Tools for population genetic analyses (TFPGA) version 1.3. Department of Biological Sciences- Box 5640 Northern Arizona University, Flagstaff, AZ 86011-5640.

Meejui, O., S. Sukmanomon and U. Na-nakorn, 2005. Allozyme revealed substantial genetic diversity between hatchery stocks of Siamase fighting fish, Betta splendens, in the province of Nakornpathom, Thailand. Aquaculture, 250:110-119.

Morizot, D.C. and M.E. Schmidt,1990. Starch gel electrophoresis and histochemical visualizations of proteins, pp 23-84. In Whitemore, D.H. (ed) Electrophoretic and electro focusing techniques in fisheries management. CRC Press, Florida.

Nei, M.,1972. Genetic distance between populations. American Naturalist, 106(949):283-292.

Nei, M.,1978. Estimation of average heterozygosity and genetic distance from a small number of individuals. Genetics, 89:583-590.

$\mathrm{Ng}$, C.K., 2004. King of the rivers: Mahseer in Malaysia and the region. Inter Sea Fishery (M). SDN BHD, Kaula Lumpur. 170 p.

Nguyen, T.T., B. Ingram, S. Sungan, G. Gooley, S.Y. Sim, D. Tinggi and S.S. De Silva, 2005. Mitochondrial DNA diversity of broodstock of two indigenous mahseer species, Tor tambroides and T. douronensis (Cyprinidae) cultured in Sarawak, Malaysia. Aquaculture, xx, xxx-xxx, doi: 10.1016/j.aquaculture.

Norris, A.T., D.G. Bradley and E.P. Cunningham,1999. Microsatellite genetic variation between and within farmed and wild Atlantic salmon (Salmo salar) populations. Aquaculture, 180:247264.

Raymond, M.L. and F. Rousset,1995. An exact test for population differentiation. Evolution, 49:1280-1283.

Rice, W.R.,1989. Analyzing tables of statistical tests. Evolution, 43:223-225.

Shaklee, J.B., F.W. Allendrof, D.D. Morizot and G.S. Whitt,1990. Gene nomenclature of protein coding loci in fish. Trans. Amer. Fish. Soc., 119:2-15.

Simmons, M., K. Mickett, H. Kucuktas, P. Li, R Dunham and Z. Liu, 2006. Comparison of domestic and wild channel catfish (Ictalurus punctatus) populations provides no evidence of genetic impact. Aquaculture, 252:133-146.

Swar D.B., 2002. The status of coldwater fish and fisheries in Nepal and prospects of their utilization for poverty reduction. In Petr T. and S.B. Swar (eds), Cold water fisheries in the trans-Himalayan region. FAO Fisheries Technical Paper No. 431:376 p.

Tave, D.,1986. Genetics for fish hatchery managers. AVI Publishing Company, Inc., Westport, Connecticut, $299 \mathrm{p}$.

Utter, F., 2003. Genetic impacts of fish introductions. In Hallerman, E. (ed) Population genetics, principles and applications for fisheries scientists. American Fisheries Society, Bethesda, 
MD, pp 357-378.

Vrijenhoek, R.C., M.E. Douglas and G.K. Meffe,1985. Conservation genetics of endangered fish populations in Arizona. Science, 229:400-402.

Weir, B.S. and C.C. Cockerham,1984. Estimating F-statistics for the analysis of population structure. Evolution, 38(6):1358-1370.

Wright, S., 1951.The genetic structure of populations. Ann. Eugen., 15:323-354.

Wright, S.,1978. Variability within and among natural populations, evolution and the genetics of populations. Vol. 4. University of Chicago Press, Chicago. $580 \mathrm{p}$.

Yeh, F.C. and T. Boyle,1997. POPGENE Version 1.32. Mocrosoft windows-based software for population genetics analysis (Computer program). University of Alberta and Centre for International Forestry Research, Alberta, Canada.

\section{AUTHOR'S ADDRESS}

Suresh K. Wagle ${ }^{1}$, Neeta Pradhan ${ }^{1}$ and Tek B. Gurung ${ }^{1}$

Fisheries Research Division, P. O. Box 13342, Godavari, Lalitpur, Nepal

(email: waglesk@yahoo.com)

Jay D. Bista ${ }^{2}$

Fisheries Research Center, P.O. Box 274, Pokhara, Nepal 